\title{
EDITORIAL
}

\section{WHAT DO THE INITIALS ASTIN ACTUALLY STAND FOR?}

This question constituted a competition at a recently held actuarial conference. From the about 150 entries let me mention

Au Secours, mon Tarif est INutilisable

and the winning entry

Accountancy Seems Tremendously Interesting Now.

Though the above competition was obviously a tongue in cheeck one, the basic question still remains. Other actuaries have used these pages before in trying to give a sensible answer, see for instance the guest editorial Arne (1990) or the editorials Lemaire (1987) and Reid (1988). I urge the reader to look once more at these interesting publications. The best summary of their arguments is still to be found in the Editorial Policy on the opposite page. ASTIN, as a section of the IAA, and the ASTIN BULLETIN do indeed stand for a forum for any quantitative point of view attacking theoretical and applied problems in any field faced with elements of insurance and risk. Those who wrote these words were wise. Indeed we need such a broad interpretation especially now where deregulation rules, finance and insurance are finding exciting ways in which to combine complementary expert knowledge from both sides and even our own actuarial societies are undergoing basic structural changes more and more blurring once sharp boundaries between countries (in education say) or specific actuarial activities (life versus non-life, asset versus liability modelling for instance).

I personally find it a great challenge to help in shaping the BULLETIN as a top journal in insurance. But let me stress from the start, ASTIN BULLETIN is a society journal. We, the members of ASTIN, shape its content, we are solely responsible for its quality, we all take on the duty in presenting to the world at large a mirror image of the state-of-the-art in actuarial modelling. My answer to the question asked in the title of this Editorial would therefore be: "ASTIN stands for the finest in actuarial modelling". I personally strongly believe that we should move away from interpreting ASTIN solely as an acronym for Actuarial STudies In Non-life insurance, and indeed continue on the road towards making the ASTIN BULLETIN the finest in the general and much wider field of the mathematics of insurance and its application. As new incoming Editor I very much rely on you, the reader, to make sure that this ultimate goal is reached. As from the next issue, René Schnieper and myself will take over as Co-Editor, respectively Editor in succession of Alois Gisler and Hans Bühlmann. The reason that I am at all able to formulate the high goals of quality set out above is entirely due to their work together with the other Editor, Co-Editor and Editorial Board, and therefore

\section{Many Thanks!}

Indeed many thanks in the name of the actuarial profession at large, and the ASTIN membership more in particular to Hans Bühlmann and Alois Gisler for their 
invaluable contribution to the well-being of our journal. I find it an honour to have been found fit to replace Hans Bühlmann as Editor. As one member of the ASTIN Committee rightly put it to me: "These are some very big shoes to step into!" That a "Swiss duo" has been proposed to replace Hans Bühlmann and Alois Gisler only stresses once more their excellent handling of affairs.

Finally, I also would like to say thanks to those remaining on board. As much as the shaping of the BULLETIN was teamwork in the past, it will stay like that in the future. As I already stressed above, every society journal thrives on the unselfish input of many. That I am able to start working with such a fine group of colleagues makes me proud. I hope that I will fulfill their expectations.

Many more words of thanks could have been added. I know however that the greatest gift we can give to Hans Bühlmann and Alois Gisler will be the quality of forthcoming ASTIN issues: let us therefore do our utmost to please them!

Paul EMBREChTS

ETH-Zürich

\section{REFERENCES}

ARne, B. (1990) The impossible ASTIN, Astin Bulletin 20 (2), 117-118.

Lemaire, J. (1987) Could ASTIN do better? Astin Bulletin 17 (1), 1-3.

ReID, H. (1988) The dimensions of ASTIN, Astin Bulletin 18 (2), 117-119. 